\title{
Transgenerational acclimation of fishes to climate change and ocean acidification
}

\author{
Philip L. Munday
}

Address: ARC Centre of Excellence for Coral Reef Studies, and College of Marine and Environmental Sciences, James Cook University, Townsville, QLD 4814, Australia

Email: philip.munday@jcu.edu.au

Fl000Prime Reports 2014, 6:99 (doi:10.12703/P6-99)

All FI000Prime Reports articles are distributed under the terms of the Creative Commons Attribution-Non Commercial License (http://creativecommons.org/licenses/by-nc/3.0/legalcode), which permits non-commercial use, distribution, and reproduction in any medium, provided the original work is properly cited.

The electronic version of this article is the complete one and can be found at: http://fl 000.com/prime/reports/b/6/99

\begin{abstract}
There is growing concern about the impacts of climate change and ocean acidification on marine organisms and ecosystems, yet the potential for acclimation and adaptation to these threats is poorly understood. Whereas many short-term experiments report negative biological effects of ocean warming and acidification, new studies show that some marine species have the capacity to acclimate to warmer and more acidic environments across generations. Consequently, transgenerational plasticity may be a powerful mechanism by which populations of some species will be able to adjust to projected climate change. Here, I review recent advances in understanding transgenerational acclimation in fishes. Research over the past 2 to 3 years shows that transgenerational acclimation can partially or fully ameliorate negative effects of warming, acidification, and hypoxia in a range of different species. The molecular and cellular pathways underpinning transgenerational acclimation are currently unknown, but modern genetic methods provide the tools to explore these mechanisms. Despite the potential benefits of transgenerational acclimation, there could be limitations to the phenotypic traits that respond transgenerationally, and trade-offs between life stages, that need to be investigated. Future studies should also test the potential interactions between transgenerational plasticity and genetic evolution to determine how these two processes will shape adaptive responses to environmental change over coming decades.
\end{abstract}

\section{Introduction and context}

Rising temperatures and ocean acidification are serious threats to marine ecosystems $[1,2]$. Shifts in geographic distributions and the timing of life history events that are consistent with ocean warming have already been observed in a variety of marine species [3], and an everincreasing number of laboratory experiments have documented potentially devastating effects of projected warming and acidification on the physiology, life history, and ecology of marine organisms. Yet it is unclear whether we can reliably predict the future impacts of climate change and ocean acidification because the majority of experiments conducted to date do not consider the potential for populations to acclimate or adapt to a changing environment $[4,5]$. While anthropogenically induced warming and acidification are progressing at rates unprecedented in the recent geological past $[1,6]$, these physical changes will occur over a number of generations for most marine species. Consequently, predictions about the impacts of climate change and ocean acidification need to consider whether marine organisms might adapt over the timeframe that environmental changes are occurring $[5,7]$. Indeed, models suggest that the impacts of climate change and ocean acidification can be very different when the potential for acclimation and adaptation is included $[8,9]$.

There are two ways that organisms can maintain or improve their performance in a new environment: acclimation or adaptation. Acclimation involves phenotypically plastic responses in physiology, morphology, or behavior that can help maintain fitness in a new environment [10] (see definition section). In contrast, 
adaptation involves selection on genetic variation that shifts the average phenotype toward the fitness peak. Owing to the different mechanisms involved, acclimation can occur over short timescales, whereas adaptation typically requires many generations. Most studies of acclimation involve phenotypic plasticity to environmental variation within a generation. For example, animals living at mid-latitudes are well known for the ability to acclimate their morphology, physiology, and life histories to the seasonal shift in temperature they experience [11]. However, some organisms can also acclimate their morphology, physiology, or life histories across generations. Here, the performance of one generation in a particular environment is improved when the previous generation also experienced that environment. This "transgenerational acclimation" is also referred to as "transgenerational plasticity" and has been defined as occurring when the environment experienced by the parents shapes the reaction norm of their offspring [12]. A classic example of transgenerational plasticity is the induction of a defensive morphology in the offspring and grand-offspring of Daphnia (waterfleas) [13]. More Daphnia offspring develop a protective helmet spine if their parents or grandparents were exposed to chemical cues of predators during pregnancy. Transgenerational plasticity is part of a larger field of study into non-genetic inheritance $[14,15]$, defined as "any effect on the offspring phenotype brought about by the transmission of factors other than DNA sequences from parents or more remote ancestors" [15]. The factors transmitted between generations can be nutritional, somatic, cytoplasmic, or epigenetic in nature (Figure 1). Non-genetic inheritance includes biological processes that have been studied for decades, such as maternal effects due to nutritional provision by the mother $[16,17]$, and processes of intense recent research interest, such as epigenetic inheritance $[14,18-20]$. The key point in all cases is that the environment experienced in one generation can affect the phenotype of subsequent generations.

\section{New transgenerational research with fishes}

There has been a recent surge of interest in transgenerational plasticity because of the implications for predicting the impacts of climate change $[12,21]$. Because multiple generations will be exposed to warming and ocean acidification over coming decades, there is potential for animals to acclimate to these environmental changes through transgenerational plasticity $[5,7]$. To date, the best examples

Figure I. Parents influence the phenotype of their offspring through both genetic and non-genetic pathways

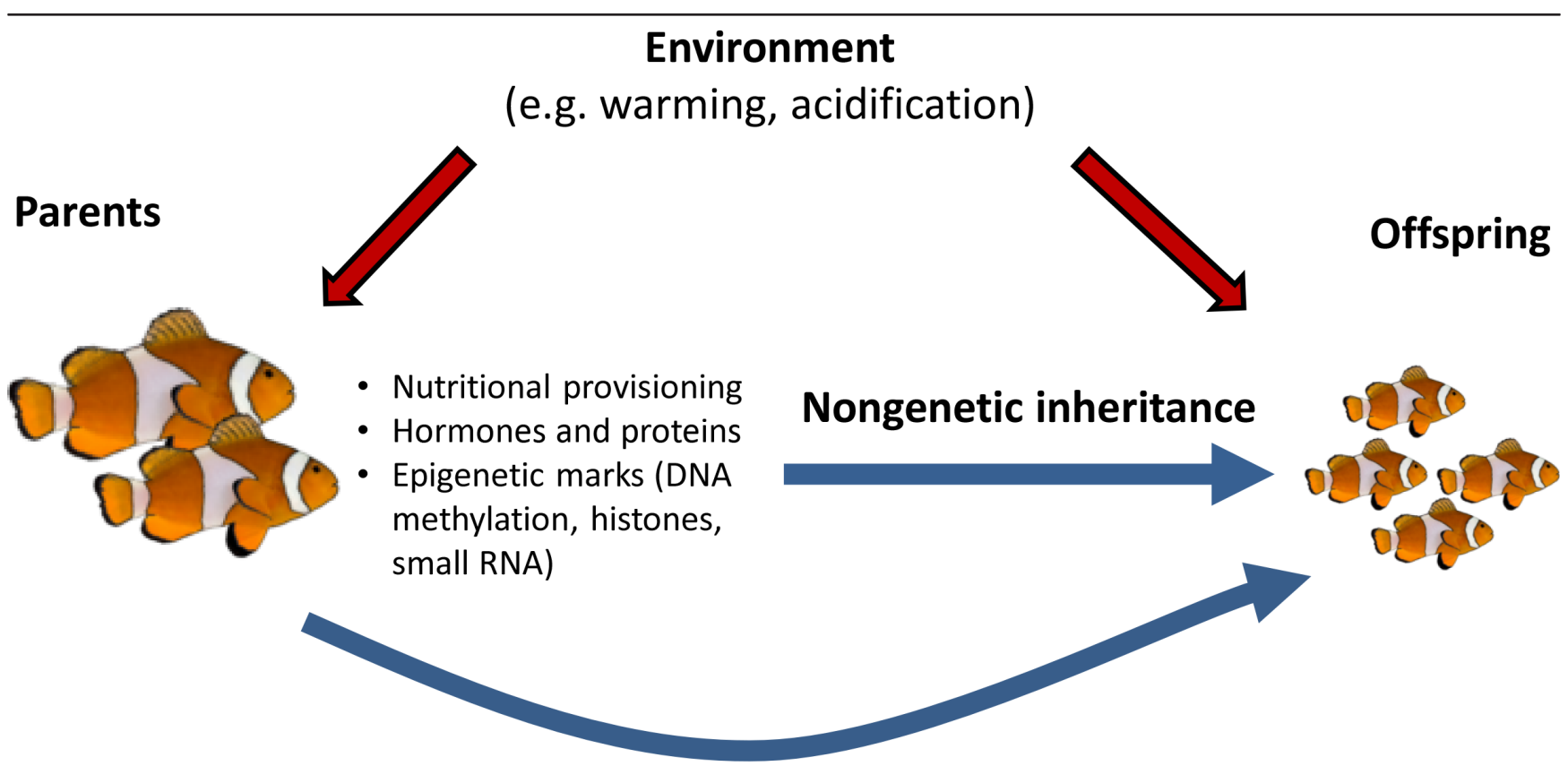

\section{Genetic inheritance}

The environment experienced by parents can influence the phenotype of their offspring through a variety of non-genetic mechanisms. For fishes, such mechanisms include nutritional provisioning of eggs, transfer of hormones or proteins to eggs, or epigenetic marks from either the mother or father. For demersal-spawning fishes, parental egg care could also potentially influence offspring phenotypes. Transgenerational acclimation occurs when the performance of offspring in a particular environment is improved when parents have experienced the same environment. 
of transgenerational acclimation to warming and acidification come from fishes. Donelson and colleagues [22] were the first to show that negative effects of warming in fishes could be completely ameliorated when several generations experienced the same elevated temperatures. Owing to its suitability to breeding and rearing in captivity, the spiny damselfish Acanthochromis polyacanthus has become a model species for studying the impacts of climate change in reef fishes. In this species, a temperature increase of just 1.5 to $3.0^{\circ} \mathrm{C}$ above the current-day summer average, well within the range predicted by climate change models, has highly significant effects on metabolic performance, growth, and reproduction [23-26]. Donelson and colleagues reared spiny damselfish for three generations (adult breeding pairs and two generations of their offspring) at control $\left(+0.0^{\circ} \mathrm{C}\right)$ and two elevated temperatures $\left(+1.5\right.$ and $\left.+3.0^{\circ} \mathrm{C}\right)$. In the F2 generation, juveniles from control parents that were exposed to the higher temperatures for several weeks exhibited a significant decline in aerobic scope, a metabolic trait essential to the performance of fishes and other marine organisms [27-30]. Juvenile fishes that had been raised at higher temperatures since hatching also had a much lower aerobic scope compared with controls. In contrast, the aerobic scope of fished reared at higher temperatures was similar to that of control fish tested at control temperatures if their parents had been reared at higher temperatures (Figure 2). In other words, there was complete acclimation of aerobic scope to elevated temperature when both parents and their offspring experienced the same high-temperature environment.

Salinas and Munch [31] found similar transgenerational plasticity in the sheepshead minnow, Cyprinodon variegatus. Juveniles grew faster at higher temperatures if their parents had been exposed to the high temperature. The authors also demonstrated a trade-off in performance, with juveniles from high-temperature parents growing more slowly than juveniles from low-temperature parents when they were reared at lower temperatures [31]. Thus, the thermal reaction norm of the offspring was dependent on the thermal environment experienced by the parents. In an elegant new study using a split-clutch breeding design that could partition maternal and paternal contributions to offspring traits, Shama and colleagues [32] demonstrated partial thermal acclimation of growth through transgenerational plasticity in a marine population of three-spine sticklebacks, Gasterosteus aculeatus. Juvenile sticklebacks reached a larger size when reared in the same thermal environment as their mothers, whereas paternal environment had little influence on juvenile growth rate. The transgenerational effects were larger and persisted longer in the warmer treatments, indicating that the improvements in growth rate are especially relevant to climate change projections. Furthermore, size differences
Figure 2. Transgenerational acclimation of aerobic scope in the spiny damselfish Acanthochromis polyacanthus
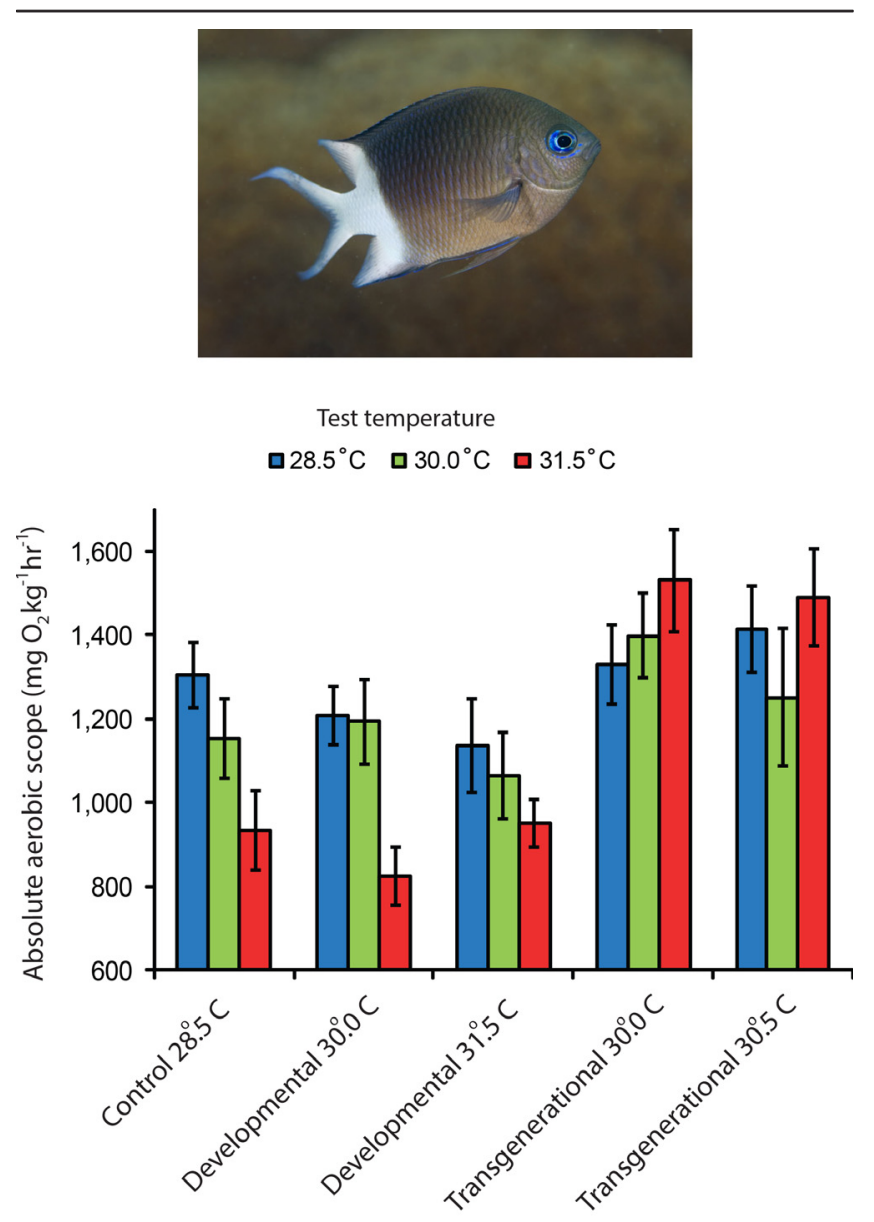

Rearing temperature

Absolute aerobic scope (the capacity for oxygen uptake above resting metabolic rate) of damselfish was tested at three temperatures $\left(28.5^{\circ} \mathrm{C}\right.$, $30.0^{\circ} \mathrm{C}$, and $31.5^{\circ} \mathrm{C}$ ) for juveniles that had been reared at $28.5^{\circ} \mathrm{C}$ (control $28.5^{\circ} \mathrm{C}$ ), $30.0^{\circ} \mathrm{C}$ (developmental $30.0^{\circ} \mathrm{C}$ ), or $31.5^{\circ} \mathrm{C}$ (developmental $31.5^{\circ} \mathrm{C}$ ) and in fish reared at $30.0^{\circ} \mathrm{C}$ or $31.5^{\circ} \mathrm{C}$ whose parents were also raised at $30.0^{\circ} \mathrm{C}$ or $31.5^{\circ} \mathrm{C}$ (transgenerational $30.0^{\circ} \mathrm{C}$ and transgenerational $31.5^{\circ} \mathrm{C}$, respectively). Aerobic scope declined sharply at $30.0^{\circ} \mathrm{C}$ and $31.5^{\circ} \mathrm{C}$ compared with $28.5^{\circ} \mathrm{C}$ in control $28.5^{\circ} \mathrm{C}$, developmental $30.0^{\circ} \mathrm{C}$, and developmental $31.5^{\circ} \mathrm{C}$ groups. However, aerobic scope at elevated temperatures was fully restored to control levels in the transgenerational $30.0^{\circ} \mathrm{C}$ and $31.5^{\circ} \mathrm{C}$ groups. Rearing temperatures refer to the maximum summer rearing temperatures in the experiment. Figure modified from Donelson and colleagues [22]. Photo courtesy of Joao Krajewski.

between temperatures established in the juveniles at warmer temperatures were still evident in the F1 adults, demonstrating that transgenerational acclimation can have long-lasting effects that ultimately may influence reproduction and other fitness-related traits. Together, these studies show that transgenerational acclimation 
could be a powerful mechanism by which marine fishes might adjust to higher ocean temperatures in the future.

Transgenerational acclimation is not restricted to elevated temperatures. Miller and colleagues [33] found that the negative effects of higher carbon dioxide $\left(\mathrm{CO}_{2}\right)$ levels and seawater acidification on the growth and survival of the anemonefish, Amphiprion melanopus, were absent in juveniles whose parents had been exposed to high $\mathrm{CO}_{2}$. A similar phenomenon was recently described in natural populations of Atlantic silverside [34]. Juveniles spawned early in the season, when parents experienced relatively high seawater $\mathrm{pH}$, were highly sensitive to acidified seawater. Survival was 33\% to 54\% lower for juveniles reared in acidified water compared with controls. Later in the season, however, when parents experienced much lower seawater $\mathrm{pH}$ while spawning, the survival of juveniles reared in acidified water was similar to that of controls [34]. Clearly, the spawning environment experienced by the adults had a significant effect on offspring performance in low-pH water. In zebrafish, exposure of adults to hypoxia for 2 to 4 weeks immediately before spawning increases hypoxia tolerance in the offspring by approximately $30 \%$ [35]. These studies suggest that transgenerational acclimation may be a general phenomenon in fishes and not just relevant to rising temperatures.

\section{How does transgenerational acclimation work?}

Improved performance in offspring from parents that have experienced warmer or more acidified conditions could occur because (a) parents in warmer or more acidic environments provide more or better nutrition to their offspring (for example, larger yolk reserves in the egg); (b) they transmit beneficial proteins, hormones, or other somatic factors directly to the offspring; or (c) they transfer epigenetic marks that beneficially influence gene regulation in the environment experienced by both the parents and offspring (Figure 1). These alternatives are not easy to distinguish and may not be mutually exclusive. In three of the studies conducted to date, there was no effect of maternal environment on egg size [22,32,33], which suggests that mothers from warmer or more acidic environments were not simply producing larger or better provisioned offspring. Whether other nutritional or somatic factors were transferred between mothers and offspring is unknown and this could be a useful area of future research. Importantly, Shama and colleagues [32] found that mitochondrial respiration rates in offspring matched the patterns of transgenerational plasticity in juvenile body size. Mitochondrial respiration in heart tissue depended on both assay temperature and the temperature experienced by the mother but not the temperature experienced by the father. Respiration rates were lower at $21^{\circ} \mathrm{C}$ if the mother had been raised at $21^{\circ} \mathrm{C}$ compared with $17^{\circ} \mathrm{C}$. As mitochondria are maternally inherited and transgenerational thermal acclimation in their study depended only on the maternal environment, it seems likely that mothers exposed to higher temperatures adjusted the metabolism of their mitochondria and that this acclimatory response then was transferred to their offspring. Similarly, Miller and colleagues [33] found that transgenerational acclimation of growth rates in anemonefish juveniles was closely correlated with acclimation of resting metabolic rates, suggesting a strong link between metabolic pathways and the transgenerational expression of life history traits. However, the molecular mechanisms that enable the transmission of beneficial regulation of metabolic pathways between generations are unknown.

Modern transcriptomic approaches that can compare patterns of gene expression in animals exposed to different environmental conditions offer a powerful means to distinguish the molecular and cellular processes that underpin transgenerational acclimation. By correlating levels of gene expression and acclimating phenotypic traits (for example, metabolic rate) in animals exposed to different experimental treatments, it should be possible to distinguish the major molecular pathways associated with transgenerational acclimation. Such molecular approaches have already been used to examine molecular responses to thermal stress $[36,37]$ and ocean acidification [38] within generations in some marine organisms and can also be applied to transgenerational studies $[39,40]$. Once candidate genes and molecular pathways of transgenerational acclimation have been identified, other genetic and experimental approaches could be applied to determine any role for epigenetic factors (for example, DNA methylation) in regulating gene expression across generations $[19,41]$ and to examine the relative importance of plasticity and fixed genetic effects on phenotypic responses to elevated temperatures and acidification $[39,42]$.

\section{Trade-offs and limitations}

Although there is increasing evidence that transgenerational plasticity may help fish acclimate to future climate change, not all transgenerational effects are positive for the offspring. For example, survival and growth of juvenile three-spined stickleback G. aculeatus were lower in control conditions if their fathers had experienced a high $\mathrm{CO}_{2}$ environment [43]. Consequently, there were carry-over effects of a high $\mathrm{CO}_{2}$ environment that caused offspring to perform poorly under conditions different to those experienced by their fathers. Similar carry-over effects have been observed for a range of other environmental stressors and indicate that the benefits of transgenerational plasticity can be context-dependent [44]. This means that transgenerational plasticity may be maladaptive if the offspring 
do not experience an environment similar to that of their parents. There may also be a trade-off across life history stages, such that enhanced performance from transgenerational plasticity in one life stage can have negative effects on other life stages [45]. To date, research into transgenerational acclimation to climate change has focused mostly on the performance of larvae and juveniles (but see [43]), and future studies will need to examine how the exposure to higher temperatures or acidification in one generation affects fitness-related traits throughout all life stages of subsequent generations.

There may also be limitations to the phenotypic traits that respond transgenerationally. For example, while complete restoration of life history and metabolic traits at high $\mathrm{CO}_{2}$ occurred in juvenile anemonefishes when their parents were also reared in high $\mathrm{CO}_{2}$, some behavioral effects are not fully resolved by parental exposure to high $\mathrm{CO}_{2}$. Allan and colleagues [46] tested the predator-escape response of juvenile anemonefishes at high $\mathrm{CO}_{2}$ by using a fish whose parents had been reared in either control or high $\mathrm{CO}_{2}$ environments. High $\mathrm{CO}_{2}$ affected locomotor performance and reactivity to a threat in juveniles. Parental exposure to high $\mathrm{CO}_{2}$ significantly improved some aspects of performance but did not improve juvenile responses in all of the traits that were measured. Locomotor responses were partially fully restored in juveniles whose parents had experienced high $\mathrm{CO}_{2}$, but the direction of response (turning angle) was not restored [46]. In a new study, Welch and colleagues [47] found that impaired behavior of juvenile damselfishes in high $\mathrm{CO}_{2}$ environments is undiminished when parents had been exposed to high $\mathrm{CO}_{2}$. Abnormal responses to a chemical alarm cue and reduced levels of behavioral lateralization (side turning preference) were still present in juveniles whose parents had also been raised in a high $\mathrm{CO}_{2}$ environment. This suggests that some cognitive functions have limited plasticity and that the impacts of warming and acidification may not be ameliorated by transgenerational exposure to the environmental stressor. Determining which phenotypic traits respond to transgenerational acclimation, and which do not, should be a priority for future research.

\section{Future directions and unanswered questions}

Transgenerational acclimation has been observed not only in fishes but in invertebrates as diverse as bryozoans, oysters, and copepods [48-50]. Theory predicts that transgenerational plasticity is adaptive for species from heterogeneous environments and when the environmental conditions experienced by parents is a good indicator of the conditions that offspring will experience [16]. Nevertheless, the prevalence of transgenerational plasticity among marine species, and how it relates to the scale of environmental variation they experience, is still poorly understood [45]. Comparative studies will be useful in determining which taxa, and from which habitats, are most likely to exhibit transgenerational acclimation to warming, acidification, and other anthropogenically induced environmental changes. As described above, it will also be important to determine which phenotypic traits respond transgenerationally and which do not. This knowledge will greatly enhance our ability to make predictions about the future impacts of climate change and ocean acidification on marine species.

In addition to questions about trade-offs among life stages and limitations to phenotypic traits that respond transgenerationally, we do not know whether the benefits of transgenerational acclimation are maintained in the longer term. Do the benefits accrued by offspring in one generation extend to subsequent generations? Understanding the longevity of transgenerational effects will be important in demining the benefits of this process to individual fitness and how plasticity may help populations cope with climate change in the long run.

Another key area for future research is establishing how transgenerational plasticity interacts with genetic adaptation $[5,21,42]$. Transgenerational acclimation may help buffer populations against the detrimental effects of climate change and ocean acidification, at least in the short term. In doing so, it may buy time for genetic adaptation to catch up with the rapid pace of environmental change [5,51]. However, a number of key questions remain to be answered before the value of transgenerational acclimation to climate change adaptation can be properly evaluated. It is possible that transgenerational plasticity could alter the rate of genetic adaptation by shifting the mean phenotype, and thus the strength or direction of selection, without genetic change. If selection acts on traits expressed by phenotypic plasticity, it is possible that phenotypic change can become decoupled from the genetic change [52]. Alternatively, new theoretical models suggest that populations can adapt faster where natural selection acts on both genetic and epigenetic variation [20]. Experimental tests of how transgenerational plasticity and genetic adaptation interact will be critical for understanding the trajectory of population responses to a rapidly changing climate over coming decades.

\section{Definition: acclimation versus acclimatization}

Here, the term acclimation is used in the broad sense to refer to laboratory- or experiment-based acclimation and natural acclimatization. Traditionally, acclimation has been used to describe phenotypically plastic responses observed in the laboratory and experimental manipulations, whereas acclimatization has been used to describe phenotypically plastic responses in natural populations. 
This distinction has caused considerable confusion in the literature, and I argue that it is an unnecessary complication, especially as more experiments are conducted in natural populations and because many of the environmental disturbances that animals are now responding to in nature, such as climate change, have an anthropogenic origin. The distinction between acclimation and acclimatization came about when physiological experiments were routinely conducted under controlled conditions in the laboratory, isolated from natural populations. In the laboratory, one or several environmental factors are manipulated, while all other factors are held constant, to determine whether individuals modify their physiology, morphology, or behavior in response to the change. In nature, a range of other environmental variables might co-vary with the variable of interest. Over recent decades, there has been an increasing use of experiments in nature where phenotypic plasticity can be studied in context with the full range of environmental conditions and ecological interactions relevant to the organisms being studied. Consequently, the division between laboratory experiments and nature has become blurred. More importantly, in my opinion, the aim of experiments in biology is to describe and understand processes that occur in natural populations. Therefore, the distinction between acclimation and acclimatization is logically meaningless. If our experiments are designed to test and understand natural processes, why should we give the process a different name when we study it in the laboratory compared with when it occurs in nature?

\section{Disclosures}

The author declares that he has no disclosures.

\section{Acknowledgments}

Philip Munday's research is supported by funding from the Australian Research Council (ARC) and the ARC Centre of Excellence for Coral Reef Studies. Special thanks to the students and postdoctoral fellows who have contributed enormously to this area of study, especially Jennifer Donelson, Gabrielle Miller, and Megan Welch. Thanks also to the staff from the Marine and Aquaculture Research Facilities Unit for their ongoing assistance and dedication to multigenerational rearing experiments.

\section{References}

I. Hoegh-Guldberg O, Mumby PJ, Hooten AJ, Steneck RS, Greenfield P, Gomez E, Harvell CD, Sale PF, Edwards AJ, Caldeira K, Knowlton N, Eakin CM, Iglesias-Prieto R, Muthiga N, Bradbury RH, Dubi $\mathrm{A}$, Hatziolos ME: Coral reefs under rapid climate change and ocean acidification. Science 2007, 3 18:1737-42.

\section{FlOOOPrime}

\section{RECOMMENDED}

2. Doney SC, Ruckelshaus M, Duffy JE, Barry JP, Chan F, English CA, Galindo HM, Grebmeier JM, Hollowed AB, Knowlton N, Polovina J,
Rabalais NN, Sydeman WJ, Talley LD: Climate change impacts on marine ecosystems. Ann Rev Mar Sci 20I2, 4:II-37.

3. Poloczanska ES, Brown CJ, Sydeman WJ, Kiessling W, Schoeman DS, Moore PJ, Brander K, Bruno JF, Buckley LB, Burrows MT, Duarte CM, Halpern BS, Holding J, Kappel CV, O'Connor MI, Pandolfi JM, Parmesan C, Schwing F, Thompson SA, Richardson AJ: Global imprint of climate change on marine life. Nature Climate Change 2013, 3:919-25.

4. Pandolfi JM, Connolly SR, Marshall DJ, Cohen AL: Projecting coral reef futures under global warming and ocean acidification. Science 2011, 333:418-22.

\section{FlOOOPrime}

RECOMMENDED

5. Munday PL, Warner RR, Monro K, Pandolfi JM, Marshall DJ: Predicting evolutionary responses to climate change in the sea. Ecol Lett 2013, 16:1488-1500.

6. Doney SC: The growing human footprint on coastal and openocean biogeochemistry. Science 2010, 328:15/2-6.

\section{FlOOOPrime}

\section{RECOMMENDED}

7. Sunday JM, Calosi P, Dupont S, Munday PL, Stillman JH, Reusch, Thorsten BH: Evolution in an acidifying ocean. Trends Ecol Evol 20I4, 29: II7-25.

8. Bell G: Evolutionary rescue and the limits of adaptation. Philos Trans R Soc Lond, B, Biol Sci 20I3, 368:20I20080.

\section{FlOOOPrime
RECOMMENDED}

9. Logan CA, Dunne JP, Eakin CM, Donner SD: Incorporating adaptive responses into future projections of coral bleaching. Global Change Biol 2014, 20:125-39.

FlOOOPrime

10. Angilletta MJ: Thermal Adaptation: A Theoretical and Empirical Synthesis. New York: Oxford University Press; 2009.

II. Somero GN: Linking biogeography to physiology: Evolutionary and acclimatory adjustments of thermal limits. Front Zool 2005, 2:1.

12. Salinas S, Brown SC, Mangel M, Munch SB: Non-genetic inheritance and changing environments. Non-Genetic Inheritance 2013, I:38-50.

13. Agrawal AA, Tollrian R, Laforsch C: Transgenerational induction of defences in animals and plants. Nature 1999, 40 I:60-3.

14. Jablonka E, Raz G: Transgenerational epigenetic inheritance: prevalence, mechanisms, and implications for the study of heredity and evolution. $Q$ Rev Biol 2009, 84: I3I-76.

15. Bonduriansky R, Day T: Nongenetic inheritance and its evolutionary implications. Annu Rev Ecol Evol Syst 2009, 40: 103-25.

16. Mousseau $\mathrm{T}$ : The adaptive significance of maternal effects. Trends Ecol Evol 1998, 13:403-7.

17. Marshall DJ, Keough MJ: Complex life cycles and offspring provisioning in marine invertebrates. Integr Comp Biol 2006, 46:643-5I.

18. Ho DH, Burggren WW: Epigenetics and transgenerational transfer: a physiological perspective. J Exp Biol 2010, 213:3-16.

19. Holeski LM, Jander G, Agrawal AA: Transgenerational defense induction and epigenetic inheritance in plants. Trends Ecol Evol 2012, 27:618-26.

20. Klironomos FD, Berg J, Collins S: How epigenetic mutations can affect genetic evolution: model and mechanism. Bioessays 2013, 35:57|-8.

21. Bonduriansky R, Crean AJ, Day T: The implications of nongenetic inheritance for evolution in changing environments. Evolutionary Applications 2012, 5:192-20I.

22. Donelson JM, Munday PL, McCormick MI, Pitcher CR: Rapid transgenerational acclimation of a tropical reef fish to climate change. Nature Climate Change 20II, 2:30-2. 
23. Munday PL, Kingsford MJ, O'Callaghan M, Donelson JM: Elevated temperature restricts growth potential of the coral reef fish Acanthochromis polyacanthus. Coral Reefs 2008, 27:927-31.

24. Nilsson GE, Crawley N, Lunde IG, Munday PL: Elevated temperature reduces the respiratory scope of coral reef fishes. Global Change Biology 2009, 15:1405-12.

25. Donelson JM, Munday PL, McCormick MI, Pankhurst NW, Pankhurst PM: Effects of elevated water temperature and food availability on the reproductive performance of a coral reef fish. Mar Ecol Prog Ser 2010, 401:233-43.

26. Rummer JL, Couturier CS, Stecyk, Jonathan AW, Gardiner NM, Kinch JP, Nilsson GE, Munday PL: Life on the edge: thermal optima for aerobic scope of equatorial reef fishes are close to current day temperatures. Global Change Biol 2014, 20:I055-66.

27. Pörtner HO, Knust R: Climate change affects marine fishes through the oxygen limitation of thermal tolerance. Science 2007, 3 I 5:95-7.

\section{FlOOOPrime} RECOMMENDED

28. Pörtner HO, Farrell AP: Ecology. Physiology and climate change. Science 2008, 322:690-2.

29. Johansen JL, Jones GP: Increasing ocean temperature reduces the metabolic performance and swimming ability of coral reef damselfishes. Global Change Biology 20II, 17:297I-9.

30. Eliason EJ, Clark TD, Hague MJ, Hanson LM, Gallagher ZS, Jeffries KM, Gale MK, Patterson DA, Hinch SG, Farrell AP: Differences in thermal tolerance among sockeye salmon populations. Science 20II, 332:109-12.

\section{FlOOOPrime}

\section{RECOMMENDED}

3I. Salinas S, Munch SB: Thermal legacies: transgenerational effects of temperature on growth in a vertebrate. Ecol Lett 2012, I5: I59-63.

\section{FlOOOPrime}

\section{RECOMMENDED}

32. Shama LNS, Strobel A, Mark FC, Wegner KM: Transgenerational plasticity in marine sticklebacks: maternal effects mediate impacts of a warming ocean. Funct Ecol 2014.

33. Miller GM, Watson S, Donelson JM, McCormick MI, Munday PL: Parental environment mediates impacts of increased carbon dioxide on a coral reef fish. Nature Climate Change 20I2, 2:858-6I.

34. Murray CS, Malvezzi A, Gobler C], Baumann H: Offspring sensitivity to ocean acidification changes seasonally in a coastal marine fish. Mar Ecol Prog Ser 2014, 504: I-II.

35. Ho DH, Burggren WW: Parental hypoxic exposure confers offspring hypoxia resistance in zebrafish (Danio rerio). J Exp Biol 2012, 215:4208-16.

36. Barshis DJ, Ladner JT, Oliver TA, Seneca FO, Traylor-Knowles N, Palumbi SR: Genomic basis for coral resilience to climate change. Proc Natl Acad Sci USA 2013, I I 0: 1387-92.

37. Pespeni MH, Barney BT, Palumbi SR: Differences in the regulation of growth and biomineralization genes revealed through long-term common-garden acclimation and experimental genomics in the purple sea urchin. Evolution 2013, 67:190I-14.

38. Pespeni MH, Sanford E, Gaylord B, Hill TM, Hosfelt JD, Jaris HK, LaVigne M, Lenz EA, Russell AD, Young MK, Palumbi SR: Evolutionary change during experimental ocean acidification. Proc Natl Acad Sci USA 2013, I I 0:6937-42.
39. Runcie DE, Garfield DA, Babbitt CC, Wygoda JA, Mukherjee S, Wray GA: Genetics of gene expression responses to temperature stress in a sea urchin gene network. Mol Ecol 2012, 21:4547-62.

\section{FlOOOPrime
RECOMMENDED}

40. Mommer BC, Bell AM: Maternal experience with predation risk influences genome-wide embryonic gene expression in threespined sticklebacks (Gasterosteus aculeatus). PLOS ONE 2014, 9:e98564.

\section{FlOOOPrime}

RECOMMENDED

4I. Cortijo S, Wardenaar R, Colomé-Tatché M, Gilly A, Etcheverry M, Labadie K, Caillieux E, Hospital F, Aury J, Wincker P, Roudier F, Jansen RC, Colot V, Johannes F: Mapping the epigenetic basis of complex traits. Science 20I4, 343: I I45-8.

\section{FlOOOPrime \\ RECOMMENDED}

42. Palumbi SR, Barshis DJ, Traylor-Knowles N, Bay RA: Mechanisms of reef coral resistance to future climate change. Science 2014 , 344:895-8.

\section{FlOOOPrime}

\section{RECOMMENDED}

43. Schade FM, Clemmesen C, Mathias Wegner K: Within- and transgenerational effects of ocean acidification on life history of marine three-spined stickleback (Gasterosteus aculeatus). Mar Biol 2014, 16I:1667-76.

44. Marshall DJ: Transgenerational plasticity in the sea: contextdependent maternal effects across the life history. Ecology 2008, 89:4|8-27.

\section{FlOOOPrime}

\section{RECOMMENDED}

45. Marshall DJ, Morgan SG: Ecological and evolutionary consequences of linked life history stages in the sea. Curr Biol 201I, 21:R7|8-25.

46. Allan, Bridie JM, Miller GM, McCormick MI, Domenici P, Munday PL: Parental effects improve escape performance of juvenile reef fish in a high-CO2 world. Proc Biol Sci 2014, 281:20132179.

47. Welch JM, Watson SA, Welsh JQ, McCormick MI, Munday PL: Effects of elevated $\mathrm{CO}_{2}$ on fish behaviour undiminished by transgenerational acclimation. Nature Climate Change 20I4, 4.

48. Burgess SC, Marshall DJ: Temperature-induced maternal effects and environmental predictability. J Exp Biol 20II, 2 | 4:2329-36.

49. Parker LM, Ross PM, O'Connor WA, Borysko L, Raftos DA, Pörtner $\mathrm{H}$ : Adult exposure influences offspring response to ocean acidification in oysters. Global Change Biol 2012, 18:82-92.

50. Vehmaa A, Brutemark A, Engström-Öst J: Maternal effects may act as an adaptation mechanism for copepods facing $\mathrm{pH}$ and temperature changes. PLOS ONE 2012, 7:e48538.

5I. Hoffmann AA, Sgrò CM: Climate change and evolutionary adaptation. Nature 20II, 470:479-85.

\section{FlOOOPrime}

\section{RECOMMENDED}

52. Day T, Bonduriansky R: A unified approach to the evolutionary consequences of genetic and nongenetic inheritance. Am Nat 20II, I78:EI8-36. 